\title{
Menurunkan Problem Reject Pinhole di Proses dengan Konsep DMAIC di PT. XYZ, Purwakarta
}

\author{
Hikmat Mulyana $M^{1}$, Andira ${ }^{2}$, Nurhayati Surbakti ${ }^{3}$ \\ ${ }^{1,2}$ Faculty of Engineering, Industrial Engineering Department, President University \\ Jl. Ki Hajar Dewantara \\ Kota Jababeka, Cikarang, Bekasi - Indonesia 17550 \\ Email: ${ }^{1}$ hikmat.pu.indo@gmail.com, ${ }^{2}$ andira@president.ac.id, ${ }^{3}$ nurhayatisurbakti@gmail.com
}

\begin{abstract}
ABSTRAK
PT XYZ merupakan salah satu industri flexible manufacturing. Dalam hal mengatasi persaingan di dunia industri percetakan, PT XYZ membangun perusahaan Rotogravure pada tahun 2011. Anak perusahaan ini bergerak dalam bidang manufaktur cylinder Rotogravure yang mensuplai unit PT $\mathrm{XYZ}$. Dari beberapa tahun kebelakang semenjak didirikannya perusahaan ini, target yang seharusnya tercapai dalam 1 tahun sebanyak \pm 5760 cylinder/tahun sampai saat ini masih belum tercapai. Hal ini diakibatkan karena adanya permasalaahn di proses produksi mencapai $\pm 49.4 \%$ dan terus muncul yang mengakibatkan jadwal pengiriman terganggu, banyaknya komplain pelanggan akibat barang yang dikirimkan selalu bermasalah. Metode yang digunakan untuk proses perbaikan ini yaitu dengan sistem atau konsep dari Six Sigma yaitu DMAIC. Dari metode DMAIC tersebut tools yang digunakan untuk proses analisa diantaranya Diagram Pareto, Fishbone, 5W1H dan Data Sheet. Tools tersebut merupakan alat bantu inti yang difokuskan dalam mencari permasalahan yang sering terjadi di PT XYZ. Dari hasil perbaikan ini didapatkan desain untuk membuat alat bantu proses pembersihan, terdapat perubahan parameter pada proses produksi dengan menurunkan current density dan temperatur di mesin Copper dengan temperatur $30^{\circ} \mathrm{C}$ dan current density $20 \mathrm{~A} / \mathrm{dm}^{2}$. Penelitian dan perbaikan yang telah dilakukan didapatkan hasil $94.45 \%$ dengan total wastage pinhole sebanyak 1 unit cylinder.
\end{abstract}

Kata kunci: 7 Tools, Rotogravure, DMAIC, Elektroplating, Cylinder Making, Quality Improvement

\begin{abstract}
PT XYZ is one of the flexible manufacturing industries. In terms of overcoming competition in the printing industry, PT XYZ built the Rotogravure company in 2011. The subsidiary is engaged in manufacturing Cylinder Rotogravure which supplies PT XYZ units. From a few years back since the establishment of this company, the target that should have been reached in amount of 5760 Cylinder / year. This target hasnot been achieved. This occurs because there is a problem in the production process reaching $\pm 49.4 \%$ and continues to appear which results in a disrupted delivery schedule, many customer complaints due to the low quality goods being shipped.The method used for this improvement process is the system or concept of Six Sigma namely DMAIC. From the DMAIC method, the tools used for the analysis process are the Pareto, Fishbone, 5W1H and Data Sheet diagrams. These tools are core tools that are focused on finding problems that often occur at PT $\mathrm{XYZ}$. From the results of this improvement, a design is got to make the cleaning process aids, there were changes in parameters in the production process by reducing the current density and temperature in the Copper machine with a temperature of $30^{\circ} \mathrm{C}$ and current density of $20 \mathrm{~A} / \mathrm{dm}^{2}$. The research and improvements that have been made are $94.45 \%$ with a total pinhole wastage of 1 cylinder unit.
\end{abstract}

Keywords: 7 Tools, Rotogravure, DMAIC, Elektroplating, Cylinder Making, Quality Improvement

\section{Pendahuluan}

Rotogravure berasal dari kata roto yang artinya berputar atau putaran dan gravure yang artinya ukiran. Rotogravure dapat diartikan sebagai suatu proses dimana suatu benda (Cylinder) dilakukan proses pengukiran dengan menggunakan alat bantu pengukir (Diamond) yang menghasilkan gambar atau bentuk di benda yang diukir. (Lilien, 1972). Pada tahun 1860 Auguste Godchaux berhasil 
menciptakan teknik cetak Rotogravure reel feed dan disempurnakan kembali oleh Karl Klic (Klietsch) yang berkebangsaan Jerman dan Samuel Fawcett dari Inggris (Rebros, 2008).

Teknologi ini dikembangkan oleh William Henry Fox Talbot pada tahun 1860. Saat itu film continuous tone dari hasil penemuan fotografi dan teknik cetak rotasi dikembangkan menjadi bentuk half tone (raster). Pada tahun 1860 Auguste Godchaux berhasil menciptakan teknik cetak Rotogravure reel feed dan disempurnakan kembali oleh Karl Klic (Klietsch) yang berkebangsaan Jerman dan Samuel Fawcett dari Inggris (Rebros, 2008).

PT XYZ merupakan salah satu industri flexible manufacturing. Dalam hal mengatasi persaingan di dunia industri percetakan, PT XYZ membangun perusahaan Rotogravure Cylinder pada tahun 2011. Anak perusahaan ini bergerak dalam bidang manufaktur Rotogravure Cylinder yang mensuplai unit bisnis PT XYZ.

Dari beberapa tahun ke belakang semenjak didirikannya perusahaan ini, target yang seharusnya tercapai dalam satu tahun sebanyak \pm 5760 cylinder / tahun sampai saat ini masih belum bisa dilakukan aktual hasil dari output produksi dalam satu tahun sebesar \pm 4800 cylinder. Hal ini diakibatkan karena permasalahan pinhole $\pm 49.4 \%$ dan terus menerus muncul yang mengakibatkan jadwal pengiriman terganggu, banyaknya komplain pelanggan akibat barang yang dikirimkan selalu bermasalah yang berakibat sangat fatal di perusahaan packaging. Resiko yang diterima oleh perusahaan packaging sangat besar yaitu kehilangan beberapa pelanggan akibat keterlambatan pengiriman. Hal itulah yang menjadi dasar pemikiran untuk dilakukan perbaikan demi mewujudkan misi dari perusahaan packaging sebagai salah satu perusahaan multinasional di bidang kemasan. Dengan melakukan proses analisa di proses produksi, permasalahan-permasalahan tersebut diharapkan dapat diminimalisir bahkan dapat dihilangkan. Penerapan perbaikan secara berkesinambungan diharapkan dapat menjadi landasan dasar untuk melakukan perbaikan di perusahan ini demi tercapainya target yang diinginkan oleh perusahaan.

\section{Metode Penelitian}

Dalam penelitian ini metode yang digunakan adalah metode Six Sigma (DMAIC), Kaizen (7 Tool's) dan $5 \mathrm{~W} 1 \mathrm{H}$. Tahapan-tahapan ini digunakan untuk mempermudah proses penelitian sehingga penelitian dapat dilaksanakan secara sistematis baik itu dalam proses identifikasi, perumusan masalah, analisis dan pemecahan masalah yang akan dilakukan. Kaizen merupakan sebuah perbaikan yang dilakukan terus menerus dan melibatkan top management, manager dan para pekerja untuk melakukan perbaikan tersebut (Masaaki Imai, 2012).

Data yang digunakan dalam proses penelitian ini merupakan data sekunder dan juga data primer. Data sekunder merupakan data yang didapatkan dari laporan proses produksi sedangkan data primer merupakan data yang didapatkan dari hasil survei di lapangan. Setelah data tersebut didapatkan, data tersebut kemudian dianalisis dengan menggunakan 1. Check Sheet; 2 . Diagram Pareto; 3. Cause-Effect Diagram. Gambar 1 menunjukkan contoh cause-effect diagram.

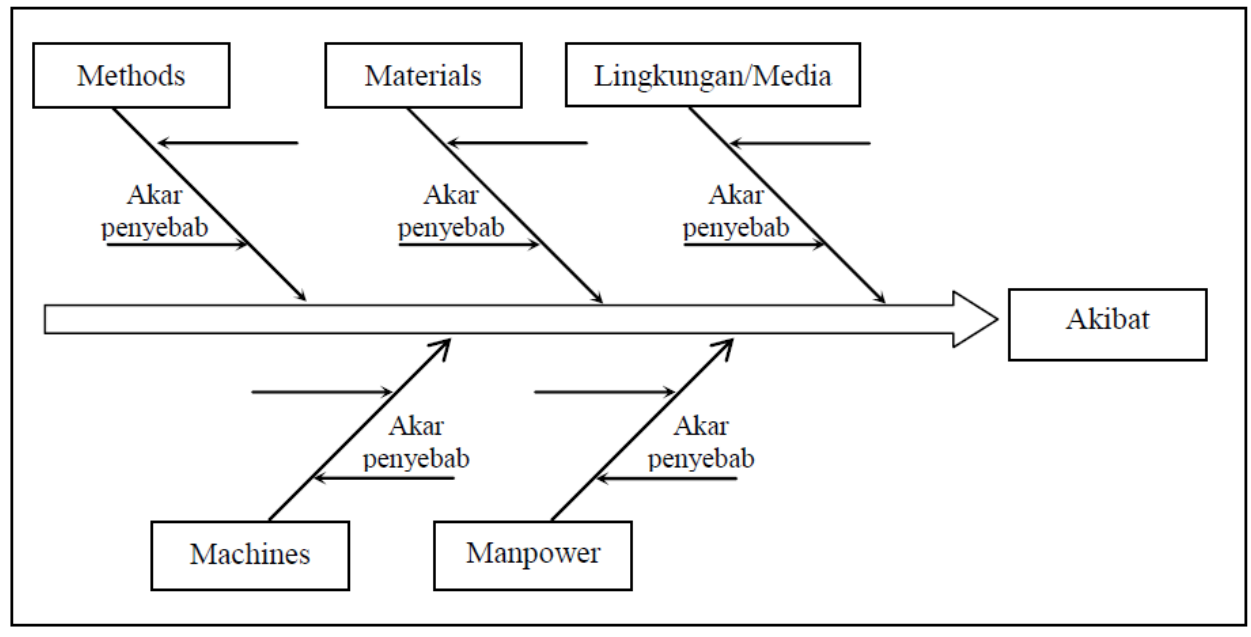

Gambar 1. Cause-effect diagram 


\subsection{Six Sigma}

Sigma merupakan sebuah abjad Yunani yang menunjukkan standar deviasi dari suatu proses. Standar deviasi mengukur variasi atau jumlah persebaran suatu rata-rata proses. Nilai sigma dapat diartikan seberapa sering cacat yang mungkin terjadi. Jika semakin tinggi tingkat sigma maka semakin kecil toleransi yang diberikan pada kecacatan sehingga semakin tinggi kapabilitas proses, dan hal itu dikatakan semakin baik.

Pengertian Six Sigma yang menurut Gaspersz, V. (2002) yang termuat dalam bukunya yang berjudul "Pedoman Implementasi Program Six Sigma Terintegrasi" dengan ISO 9001:2000, MBNQA dan HACPP adalah suatu visi peningkatan kualitas menuju target 3,4 kegagalan per sejuta kesempatan (DPMO) untuk setiap transaksi produk (barang dan/atau jasa), upaya giat menuju kesempurnaan (zero defect/kegagalan nol).

Dari beberapa definisi yang telah disebutkan maka dapat diambil kesimpulan bahwa Six Sigma adalah sebuah sistem yang komprehensif dan fleksibel untuk mencapai, mempertahankan, dan memaksimalkan sukses bisnis. Six Sigma secara unik dikendalikan oleh pemahaman yang kuat terhadap kebutuhan pelanggan, pemakaian yang disiplin terhadap fakta, data, analisis statistik, dan perhatian yang cermat untuk mengelola, memperbaiki, dan menanamkan kembali proses bisnis.

Dalam tahapan perbaikan ini metode dari konsep Six Sigma yang dipakai yaitu DMAIC, Six Sigma menggunakan alat statistik untuk mengidentifikasi beberapa faktor vital, DMAIC merupakan proses kunci untuk peningkatan secara kontinyu menuju target Six Sigma. DMAIC dilakukan secara sistematik berdasarkan ilmu pengetahuan dan fakta (systematic, scientific, and fact based). Berikut ini adalah tahapan dalam siklus DMAIC dan langkah-langkah yang harus dilaksanakan pada setiap tahap.

\subsubsection{Define (D)}

Tahap Define merupakan langkah operasional pertama dalam program peningkatan kualitas Six Sigma. Dalam tahap Define dilakukan identifikasi proyek yang potensial, mendefinisikan peran orang-orang yang terlibat dalam proyek Six Sigma, mengidentifikasi karakteristik kualitas kunci (CTQ) yang berhubungan langsung dengan kebutuhan spesifik dari pelanggan dan menentukan tujuan.

\subsubsection{Measure $(\mathrm{M})$}

Mengukur kinerja proses pada saat sekarang (baseline measurements) agar dapat dibandingkan dengan target yang ditetapkan. Lakukan pemetaan proses dan mengumpulkan data yang berkaitan dengan indikator kinerja kunci (Key Performance Indicators / KPIs). Beberapa alat bantu yang dapat digunakan:

1) Measurement System Analysis (R\&R Study, dll)

2) Basic Statistic

\subsubsection{Analyze (A)}

Menganalisa hubungan sebab akibat berbagai faktor yang dipelajari untuk mengetahui faktorfaktor dominan yang perlu dikendalikan. Tahapan yang perlu dilakukan untuk proses analisis ini yaitu dengan melakukan benchmarking terhadap key performance metric, melakukan gap analysis terhadap performa perusahaan dengan perusahaan yang di-benchmark, identifikasi sukses faktor dari benchmark, analisa dampak dan tetapkan goal improvement. Alat bantu yang dapat digunakan untuk proses analisa ini:
1) Pareto Diagram
2) Five Why and One How (5W1H)
3) Fishbone Diagram

\subsubsection{Improve (I)}

Mengoptimalisasikan proses menggunakan analisis-analisis seperti Design of Experiments (DOE) dan lain-lain, untuk mengetahui dan mengendalikan kondisi optimum proses. Tahapan yang dilakukan pada proses ini melakukan identifikasi karakteristik performa produk yang akan ditingkatkan, lakukan diagnosis terhadap karakteristik tersebut untuk mengetahui sumber utama terjadinya variabilitas, identifikasi kembali Variable Key Process dengan melakukan Design of 
Experiments, jika ada variabel yang dapat mempengaruhi tetapkan performance tolerancing / spesifikasi operasional yang baru, lakukan proses validasi usulan solusi terhadap Customer Requirement sebagaimana tertuang dalam QFD.

\subsubsection{Control (C)}

Merupakan tahap operasional terakhir dalam proyek peningkatan kualitas Six Sigma. Pada tahap ini prosedur-prosedur serta hasil-hasil peningkatan kualitas didokumentasikan untuk dijadikan pedoman kerja standar guna mencegah masalah yang sama atau praktek-praktek lama terulang kembali, kemudian kepemilikan atau tanggung jawab ditransfer dari tim Six Sigma kepada penanggung jawab proses, dan ini berarti proyek Six Sigma berakhir pada tahap ini.

\section{Analisis dan Interpretasi}

\subsection{Define}

Pada tahap awal dilakukan proses stratifikasi data, stratifikasi data bertujuan untuk melakukan pendataan secara keseluruhan problem yang ada di PT XYZ, kemudian data tersebut akan dibagi sesuai dengan permasalahan yang ada di lapangan. Data permasalahan ditunjukkan oleh Tabel 1. Untuk proses analisa awal digunakan diagram pareto dengan prinsip 80/20 dimana permasalahan berasal dari $80 \%$ masalah yang harus dihadapi, sehingga pada proses perbaikan dapat lebih terfokuskan pada permasalahan mana yang seharusnya diselesaikan.

\begin{tabular}{|c|c|c|c|c|}
\hline Problem & Waste (pcs) & Rank & $\%$ & $\%$ Cumulative \\
\hline Pinhole & 40 & 1 & 16.74 & 16.74 \\
\hline Cell Turun / Belang / Stylus patah & 26 & 4 & 10.88 & 56.07 \\
\hline Salah Design & 22 & 5 & 9.21 & 65.27 \\
\hline Gagal Engrave & 15 & 6 & 6.28 & 71.55 \\
\hline Beralur & 15 & 6 & 6.28 & 77.82 \\
\hline Oval/ Tapper & 11 & 7 & 4.6 & 82.43 \\
\hline Hardness & 5 & 8 & 2.09 & 84.52 \\
\hline Screen Kasar / Bergelombang & 5 & 8 & 2.09 & 86.61 \\
\hline HV Tinggi & 4 & 9 & 1.67 & 88.28 \\
\hline Scratch & 4 & 9 & 1.67 & 89.96 \\
\hline Gagal Chrome / Bintik & 4 & 9 & 1.67 & 91.63 \\
\hline Warna tidak Sesuai & 4 & 9 & 1.67 & 93.31 \\
\hline Corrosive & 2 & 10 & 0.84 & 94.14 \\
\hline Base Bolong & 2 & 10 & 0.84 & 94.98 \\
\hline Dekok & 2 & 10 & 0.84 & 95.82 \\
\hline Rubah Circum & 2 & 10 & 0.84 & 96.65 \\
\hline Cyl Pecah & 1 & 11 & 0.42 & 97.07 \\
\hline Tambah Copper & 1 & 11 & 0.42 & 97.49 \\
\hline Register & 1 & 11 & 0.42 & 97.91 \\
\hline Cylinder Tipis & 1 & 11 & 0.42 & 98.33 \\
\hline Raster Tipis & 1 & 11 & 0.42 & 98.74 \\
\hline Salah Circum & 1 & 11 & 0.42 & 99.16 \\
\hline Flaange Rusak & 1 & 11 & 0.42 & 99.58 \\
\hline Salah Engrave & 1 & 11 & 0.42 & 100 \\
\hline Total & 239 & & 100 & \\
\hline
\end{tabular}

Setelah dilakukan proses pengelompokan kemudian data tersebut dibuat grafik batang dan garis atau grafik diagram pareto, terlihat adanya data dengan persentase kumulatif yang sangat tinggi dari ketiga kelompok permasalahan tersebut dibandingkan dengan permasalahan yang lainnya, seperti terlihat pada Gambar 2. 


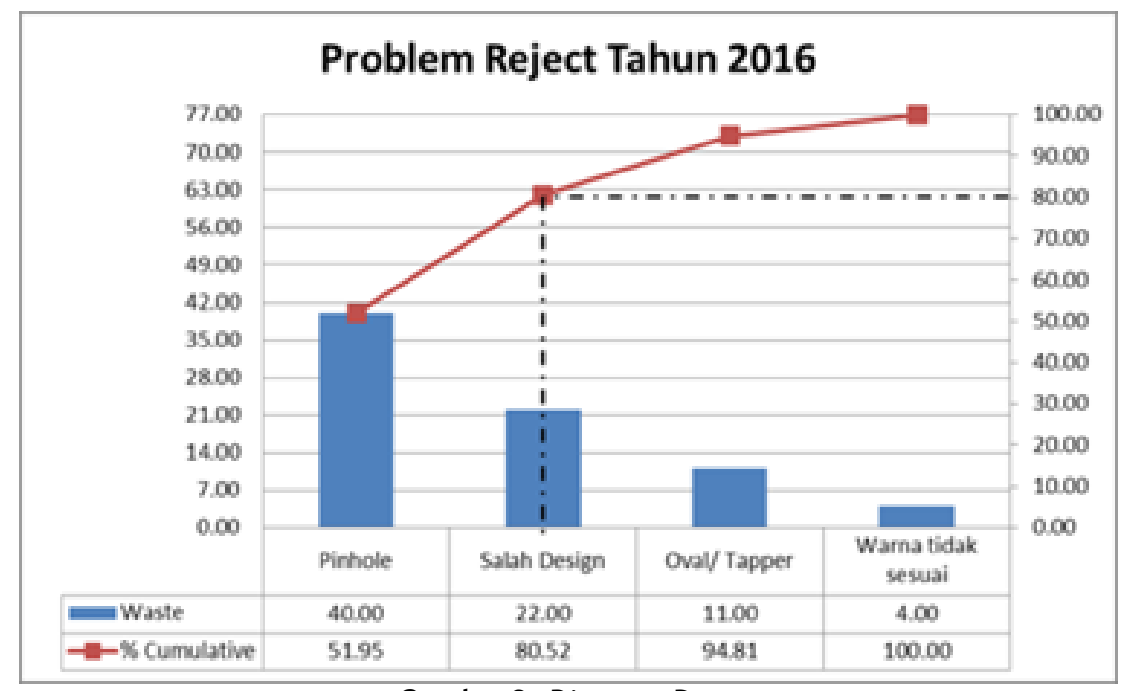

Gambar2. Diagram Pareto

\subsection{Measure \& Analyze}

Dari data tersebut terlihat dengan jelas bahwa terdapat masalah yang perlu diselesaikan yaitu pinhole dengan persentase reject sebesar $16.74 \%$ dari waste produksi. Target dari perbaikan yang akan dilakukan guna mengurangi terjadinya defect yang diakibatkan oleh pinhole adalah sebesar $5 \%$ (wastage produksi) dari defect awal pinhole sebesar $16.74 \%$ atau setara dengan menurunkan masalah tersebut sebesar $25 \%$ dari total proses produksi. Agar dapat memahami permasalahan yang terjadi maka dapat digambarkan melalui flow diagram. Gambar 3 menunjukkan flow diagram terjadinya proses pinhole cylinder di PT XYZ.

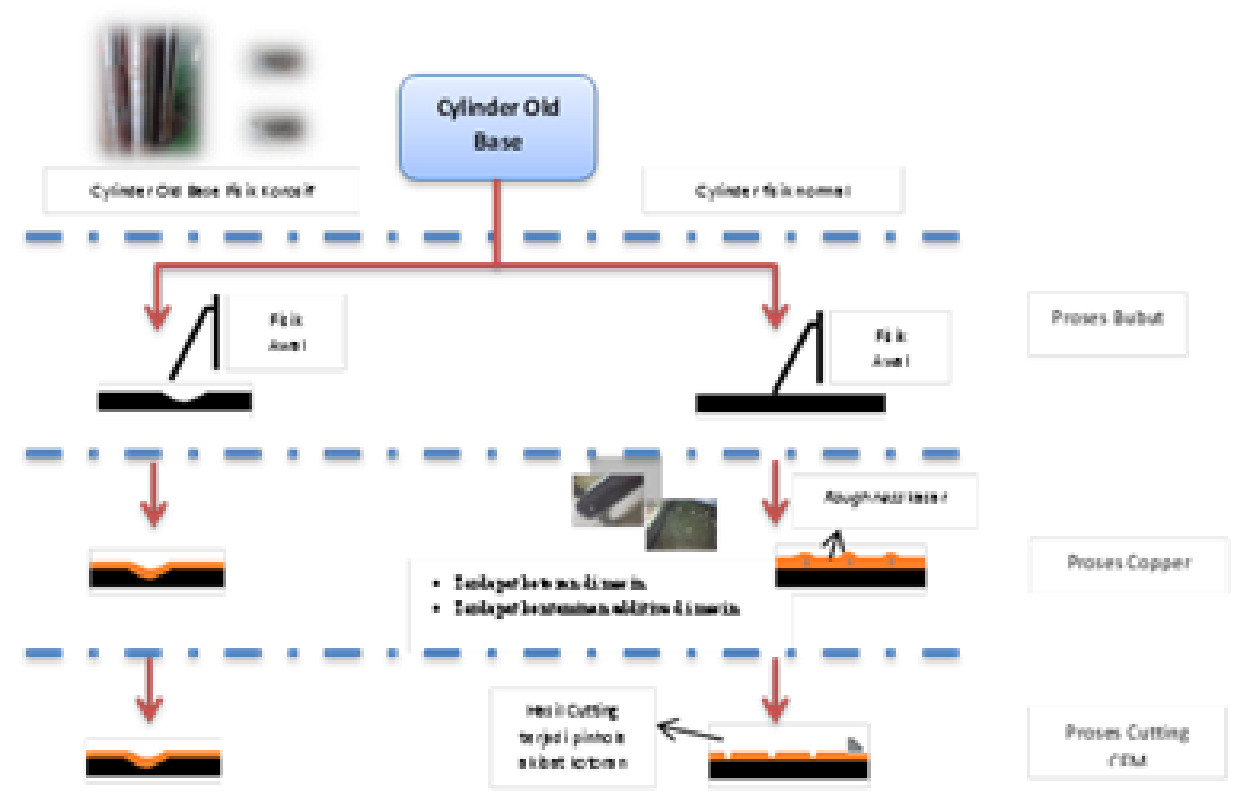

Gambar3. Flow diagram terjadinya proses pinhole pada cylinder

Fishbone diagram digunakan untuk menelusuri penyebab-penyebab terjadinya masalah pinhole, seperti terlihat pada Gambar 4. 


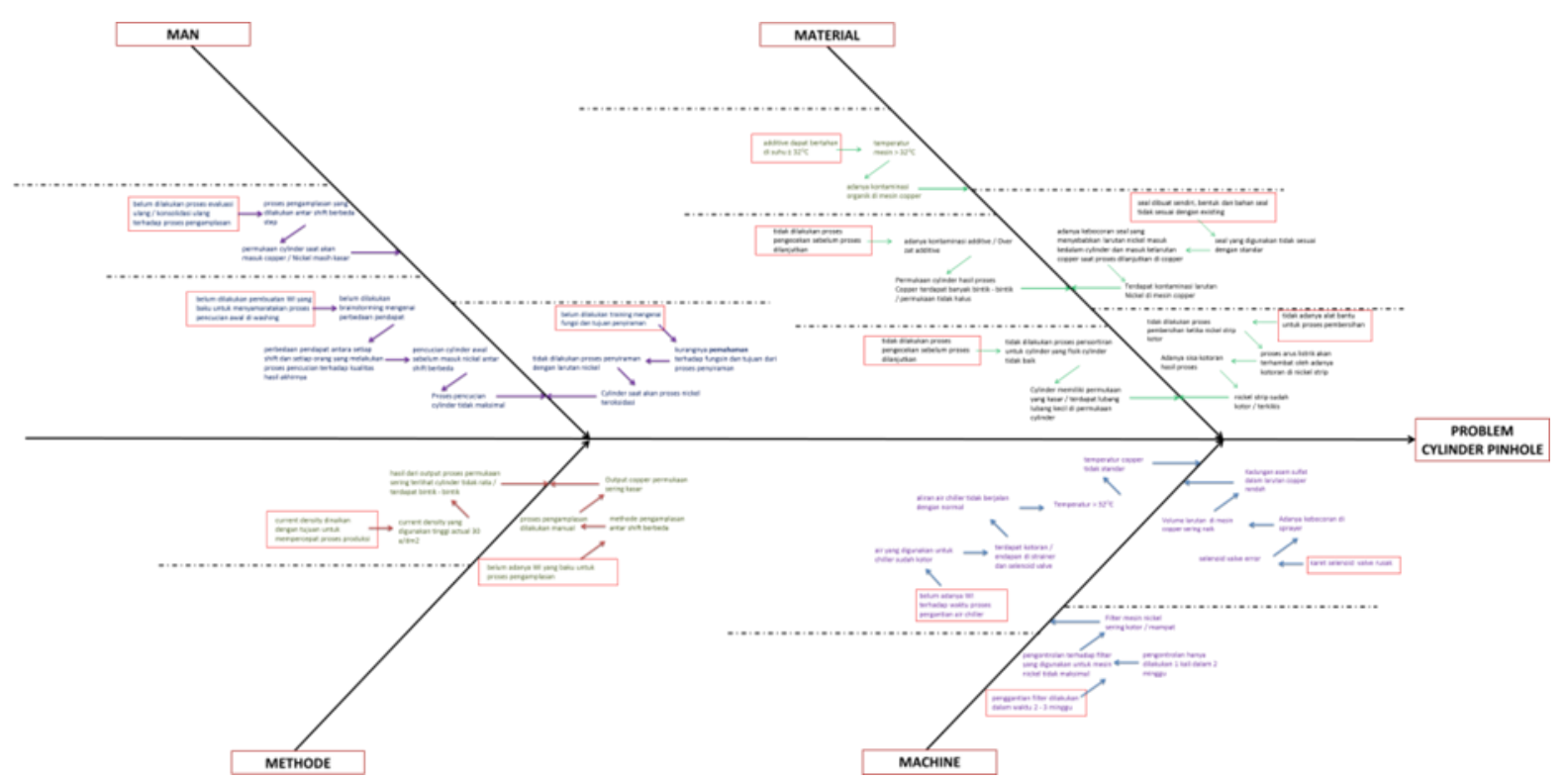

Gambar4. Fishbone diagram masalah pinhole

\subsection{Improve}

Dari hasil analisis fishbone yang disebutkan pada Gambar 4, terdapat beberapa faktor dominan yang menyebabkan permasalahan pinhole terjadi, dapat dilihat pada Tabel 2.

Tabel 2. Data Rencana Perbaikan hasil Fishbone

\begin{tabular}{|c|c|c|c|c|c|}
\hline No & Masalah & Why & Problem & Rencana Perbaikan & $\begin{array}{c}\text { Jenis } \\
\text { Perbaikan }\end{array}$ \\
\hline 1 & $\begin{array}{l}\text { Nickel strip sudah } \\
\text { kotor / terkikis }\end{array}$ & $\begin{array}{l}\text { Tidak adanya alat bantu } \\
\text { untuk proses pembersihan }\end{array}$ & Pinhole & $\begin{array}{l}\text { Menyiapkan sikat kawat untuk } \\
\text { proses pembersihan anode }\end{array}$ & Alat Bantu \\
\hline 2 & $\begin{array}{l}\text { Terdapat } \\
\text { kontaminasi larutan } \\
\text { Nickel di mesin } \\
\text { copper }\end{array}$ & $\begin{array}{l}\text { Seal dibuat sendiri, bentuk } \\
\text { dan bahan seal tidak sesuai } \\
\text { dengan existing }\end{array}$ & Pinhole & $\begin{array}{l}\text { Membuat jig yang sesuai } \\
\text { dengan ukuran }\end{array}$ & Alat Bantu \\
\hline 3 & $\begin{array}{l}\text { Cylinder memiliki } \\
\text { permukaan yang } \\
\text { kasar / terdapat } \\
\text { lubang lubang kecil } \\
\text { di permukaan } \\
\text { cylinder }\end{array}$ & $\begin{array}{l}\text { Tidak dilakukan proses } \\
\text { pengecekan sebelum } \\
\text { proses dilanjutkan }\end{array}$ & Pinhole & $\begin{array}{l}\text { Buatkan standar baku } \\
\text { terhadap syarat dari RM yang } \\
\text { akan digunakan untuk } \\
\text { cylinder-nya }\end{array}$ & SOP / WI \\
\hline 4 & $\begin{array}{l}\text { Kontaminasi senyawa } \\
\text { organik }\end{array}$ & $\begin{array}{l}\text { Terdapat kotoran / } \\
\text { endapan di strainer } \\
\text { selenoid }\end{array}$ & Pinhole & Lakukan proses pembersihan & SOP / WI \\
\hline 5 & $\begin{array}{l}\text { Kandungan asam } \\
\text { sulfat dalam larutan } \\
\text { rendah }\end{array}$ & Karet selenoid valve rusak & Pinhole & $\begin{array}{l}\text { Ganti selenoid valve yang } \\
\text { sudah usang dengan yang baru }\end{array}$ & SOP / WI \\
\hline 6 & $\begin{array}{l}\text { Output copper } \\
\text { permukaan sering } \\
\text { kasar }\end{array}$ & $\begin{array}{l}\text { Belum adanya WI yang } \\
\text { baku untuk proses } \\
\text { pengamplasan }\end{array}$ & Pinhole & $\begin{array}{l}\text { Buatkan standar baku untuk } \\
\text { proses pengamplasan dengan } \\
\text { urutan amplas yang benar, } \\
\text { dan lakukan training }\end{array}$ & SOP / WI \\
\hline 7 & $\begin{array}{l}\text { Proses pencucian } \\
\text { cylinder tidak } \\
\text { maksimal }\end{array}$ & $\begin{array}{l}\text { Belum dilakukan } \\
\text { pembuatan WI yang baku } \\
\text { untuk menyamaratakan } \\
\text { proses pencucian awal di } \\
\text { washing }\end{array}$ & Pinhole & $\begin{array}{l}\text { Buatkan WI yang baku dan } \\
\text { lakukan training untuk } \\
\text { menyamaratakan pemahaman } \\
\text { proses }\end{array}$ & SOP / WI \\
\hline 8 & $\begin{array}{l}\text { Permukaan cylinder } \\
\text { saat akan masuk } \\
\text { copper / nickel } \\
\text { masih kasar }\end{array}$ & $\begin{array}{l}\text { Belum dilakukan proses } \\
\text { evaluasi ulang / konsolidasi } \\
\text { ulang terhadap proses } \\
\text { pengamplasan }\end{array}$ & Pinhole & $\begin{array}{l}\text { Buatkan WI yang baku dan } \\
\text { lakukan training untuk } \\
\text { menyamaratakan pemahaman } \\
\text { proses }\end{array}$ & SOP / WI \\
\hline 9 & $\begin{array}{l}\text { Cylinder saat akan } \\
\text { proses nickel }\end{array}$ & $\begin{array}{l}\text { Belum dilakukan training } \\
\text { mengenai fungsi dan }\end{array}$ & Pinhole & $\begin{array}{l}\text { Lakukan proses pelatihan } \\
\text { mengenai dampak positif dan }\end{array}$ & Training \\
\hline
\end{tabular}




\begin{tabular}{|c|c|c|c|c|c|}
\hline & teroksidasi & tujuan penyiraman & & $\begin{array}{l}\text { negatif serta proses analisis } \\
\text { sebab akibat }\end{array}$ & \\
\hline 10 & $\begin{array}{l}\text { Hasil dari output } \\
\text { proses permukaan } \\
\text { sering terlihat } \\
\text { cylinder tidak rata / } \\
\text { terdapat bintik - } \\
\text { bintik }\end{array}$ & $\begin{array}{l}\text { Current density dinaikkan } \\
\text { dengan tujuan untuk } \\
\text { mempercepat proses } \\
\text { produksi }\end{array}$ & Pinhole & $\begin{array}{l}\text { Evaluasi current density yang } \\
\text { digunakan untuk proses } \\
\text { Copper }\end{array}$ & Validasi \\
\hline 11 & $\begin{array}{l}\text { Permukaan cylinder } \\
\text { hasil proses Copper } \\
\text { terdapat banyak } \\
\text { bintik - bintik / } \\
\text { permukaan tidak } \\
\text { halus }\end{array}$ & $\begin{array}{l}\text { Waktu yang digunakan } \\
\text { untuk proses dosing pump } \\
\text { additive terlalu lama }\end{array}$ & Pinhole & $\begin{array}{l}\text { Validasi dosing pump yang } \\
\text { digunakan }\end{array}$ & $\begin{array}{l}\text { Validasi } \\
\text { alat }\end{array}$ \\
\hline 12 & $\begin{array}{l}\text { Filter mesin nickel } \\
\text { sering kotor / } \\
\text { mampat }\end{array}$ & $\begin{array}{l}\text { Penggantian filter } \\
\text { dilakukan dalam waktu } 2 \text { - } \\
3 \text { minggu }\end{array}$ & Pinhole & $\begin{array}{l}\text { Lakukan evaluasi terhadap } \\
\text { waktu penggunaan filter } \\
\text { Nickel }\end{array}$ & WI \\
\hline 13 & $\begin{array}{l}\text { Adanya kenaikan } \\
\text { temperatur hingga }> \\
32^{\circ} \mathrm{C}\end{array}$ & $\begin{array}{l}\text { Belum adanya WI terhadap } \\
\text { waktu proses pergantian } \\
\text { air chiller }\end{array}$ & Pinhole & $\begin{array}{l}\text { Evaluasi ulang terhadap } \\
\text { pemakaian air chiller dan } \\
\text { lakukan proses preventif } \\
\text { untuk pengecekan strainer }\end{array}$ & WI \\
\hline
\end{tabular}

Terjadinya proses pengendapan pada katoda disebabkan oleh adanya perpindahan ion-ion bermuatan listrik dari anoda dengan perantara larutan elektrolit, yang terjadi secara terus menerus pada tegangan konstan hingga akhirnya mengendap dan menempel kuat membentuk lapisan dipermukaan benda logam. Proses elektroplating melindungi logam dasar dengan menggunakan logam-logam tertentu sebagai pelapis dan pelindung, misalnya nikel, krom, tembaga, seng dan sebagainya. (Abrianto Akuan, 2010).

\subsection{Control}

Setelah hasil dari perbaikan yang dilakukan hingga akar masalah ke-12, kemudian dilakukan rekapitulasi hasil proses produksi dari bulan Mei dan Juni, dapat dilihat pada Tabel 3 dan Tabel 4.

Tabel3. Laporan bulan Mei

\begin{tabular}{|c|c|c|c|c|}
\hline $\begin{array}{c}\text { Sample } \\
\text { /day } \\
\text { May }\end{array}$ & $\begin{array}{c}\text { Qty } \\
\text { Output } \\
\text { Copper } \\
\text { Produksi }\end{array}$ & $\begin{array}{c}\text { Qty } \\
\text { Output } \\
\text { Cylinder } \\
\text { Copper } \\
\text { (CFM) }\end{array}$ & $\begin{array}{c}\text { Reject } \\
\text { Cyl }\end{array}$ & $\begin{array}{l}\text { Reject } \\
\text { Pinhole }\end{array}$ \\
\hline 1 & 22 & 17 & 5 & 1 \\
\hline 2 & 22 & 16 & 6 & 2 \\
\hline 3 & 21 & 19 & 2 & 0 \\
\hline 4 & 19 & 16 & 3 & 0 \\
\hline 5 & 18 & 14 & 4 & 0 \\
\hline 6 & 20 & 17 & 3 & 0 \\
\hline 7 & 22 & 18 & 4 & 1 \\
\hline 8 & 21 & 14 & 7 & 1 \\
\hline 9 & 20 & 17 & 3 & 0 \\
\hline 10 & 16 & 13 & 3 & 0 \\
\hline 11 & 20 & 20 & 0 & 0 \\
\hline 12 & 17 & 14 & 3 & 1 \\
\hline 13 & 16 & 16 & 0 & 0 \\
\hline 14 & 18 & 15 & 3 & 0 \\
\hline 15 & 17 & 14 & 3 & 1 \\
\hline 16 & 18 & 15 & 3 & 0 \\
\hline 17 & 19 & 16 & 3 & 1 \\
\hline 18 & 18 & 17 & 1 & 1 \\
\hline 19 & 18 & 16 & 2 & 0 \\
\hline 20 & 20 & 18 & 2 & 0 \\
\hline
\end{tabular}

Tabel4. Laporan bulan Juni

\begin{tabular}{|c|c|c|c|c|}
\hline $\begin{array}{c}\text { Sample } \\
\text { /day } \\
\text { June }\end{array}$ & $\begin{array}{c}\text { Qty } \\
\text { Output } \\
\text { Copper } \\
\text { Produksi }\end{array}$ & $\begin{array}{c}\text { Qty } \\
\text { Output } \\
\text { Cylinder } \\
\text { Copper } \\
\text { (CFM) }\end{array}$ & $\begin{array}{c}\text { Reject } \\
\text { Cyl }\end{array}$ & $\begin{array}{c}\text { Reject } \\
\text { Pinhole }\end{array}$ \\
\hline 1 & 19 & 18 & 1 & 0 \\
\hline 2 & 20 & 19 & 1 & 0 \\
\hline 3 & 22 & 21 & 1 & 0 \\
\hline 4 & 22 & 21 & 1 & 0 \\
\hline 5 & 20 & 19 & 1 & 0 \\
\hline 6 & 21 & 20 & 1 & 0 \\
\hline 7 & 22 & 22 & 0 & 0 \\
\hline 8 & 21 & 21 & 0 & 0 \\
\hline 9 & 22 & 21 & 1 & 0 \\
\hline 10 & 23 & 22 & 1 & 0 \\
\hline 11 & 20 & 18 & 2 & 0 \\
\hline 12 & 23 & 21 & 2 & 0 \\
\hline 13 & 20 & 17 & 3 & 1 \\
\hline 14 & 22 & 22 & 0 & 0 \\
\hline 15 & 23 & 23 & 0 & 0 \\
\hline 16 & 23 & 22 & 1 & 0 \\
\hline 17 & 24 & 23 & 1 & 0 \\
\hline 18 & 24 & 23 & 1 & 0 \\
\hline 19 & 24 & 23 & 1 & 0 \\
\hline 20 & 24 & 23 & 1 & 0 \\
\hline
\end{tabular}




\begin{tabular}{|c|c|c|c|c|}
\hline $\mathbf{2 1}$ & 20 & 18 & 2 & 1 \\
\hline $\mathbf{2 2}$ & 23 & 21 & 2 & 0 \\
\hline $\mathbf{2 3}$ & 20 & 19 & 1 & 0 \\
\hline $\mathbf{2 4}$ & 18 & 17 & 1 & 0 \\
\hline $\mathbf{2 5}$ & 18 & 17 & 1 & 0 \\
\hline $\mathbf{2 6}$ & 19 & 18 & 1 & 0 \\
\hline Total & 500 & 432 & 68 & 10 \\
\hline $\begin{array}{c}\text { Rata- } \\
\text { rata }\end{array}$ & 19.231 & 16.615 & 2.615 & 0.385 \\
\hline
\end{tabular}

\begin{tabular}{|c|c|c|c|c|}
\hline $\mathbf{2 1}$ & 24 & 24 & 0 & 0 \\
\hline $\mathbf{2 2}$ & 24 & 24 & 0 & 0 \\
\hline $\mathbf{2 3}$ & 24 & 22 & 2 & 0 \\
\hline $\mathbf{2 4}$ & 24 & 23 & 1 & 0 \\
\hline $\mathbf{2 5}$ & 24 & 23 & 1 & 0 \\
\hline $\mathbf{2 6}$ & 24 & 23 & 1 & 0 \\
\hline Total & 583 & 558 & 25 & 1 \\
\hline $\begin{array}{c}\text { Rata- } \\
\text { rata }\end{array}$ & 22.423 & 21.462 & 0.962 & 0.038 \\
\hline
\end{tabular}

Dari hasil bulan Mei masih terdapat 68 cylinderreject, persentase reject yang paling besar terjadi pada proses pinhole, persentase pinhole didapatkan $14.71 \%$ dari total reject yang didapatkan. Dari hasil bulan Juni masih terdapat 25 cylinderreject dengan persentase reject problem pinhole sebesar $4.00 \%$ dari total wastagecylinder. Sangat terlihat sekali perubahan yang terjadi dengan penanganan pinhole hingga akar masalah ke-13.

Dari semua data tersebut kemudian dibuatkan rekapan data untuk memudahkan perbandingan atau perkembangan hasil perbaikan yang telah dilakukan, dapat dilihat pada Tabel 5 .

Tabel5. Data hasil proses produksi

\begin{tabular}{|l|c|c|c|}
\hline & Mei & Juni & Total \\
\hline Waste produksi & 68 & 25 & 93 \\
\hline Komplain pelanggan & 8 & 14 & 22 \\
\hline Total output & 492 & 569 & \\
\hline Total & 500 & 583 & 1083 \\
\hline
\end{tabular}

Adapun persentase dari hasil perbaikan terhadap standar wastage serta wastage sebelum dilakukan perbaikan dapat dilihat pada Tabel 6.

Tabel 6. Data komparasi hasil sebelum dan sesudah perbaikan

\begin{tabular}{|c|c|c|c|c|}
\hline $\begin{array}{c}\text { Pencapaian } \\
\text { hasil } \\
\text { perbaikan }\end{array}$ & Wastage & $\begin{array}{c}\text { Sebelum } \\
\text { perbaikan } \\
(\%)\end{array}$ & $\begin{array}{c}\text { Standar } \\
\text { wastage } \\
\text { total (\%) }\end{array}$ & $\begin{array}{c}\text { Wastage } \\
\text { setelah } \\
\text { perbaikan } \\
\text { total (\%) }\end{array}$ \\
\cline { 2 - 5 } & Pinhole & $16.74 \%$ & - & $4.00 \%$ \\
\hline
\end{tabular}

Dari hasil persentase tersebut terlihat jelas bahwa setelah perbaikan yang sudah dilakukan dapat menurunkan wastage dari total wastagerejectpinhole $16.74 \%$ menjadi $4.00 \%$. Pencapaian penurunan wastage tersebut sebesar $76.11 \%$ dibandingkan dengan sebelum perbaikan. Namun jika dilihat dari hasil output rejectcylinder yang diakibatkan pinhole hanya menghasilkan pinhole sebanyak 1 unit Cylinder. Data wastage total dan wastage pinhole bisa dilihat pada Gambar 5 dan Gambar 6.

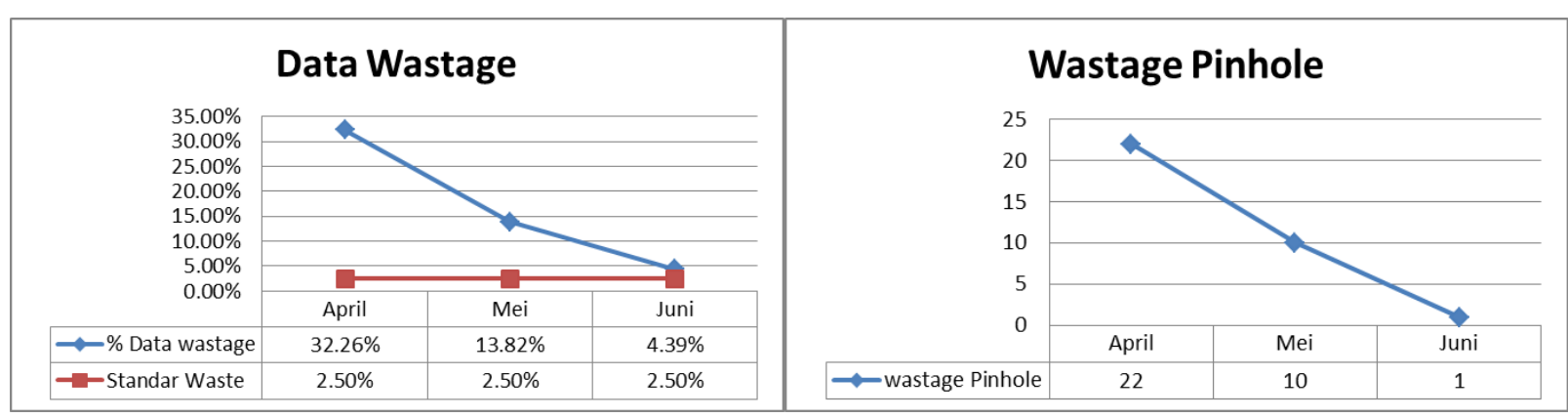

Gambar 5. Data WasteTotal

Gambar 6. Data WastePinhole

Dari hasil perbaikan yang telah diterapkan, serta telah dilakukan evaluasi terhadap hasil perbaikan, persentase keberhasilan terhadap perbaikan tersebut mencapai $95.45 \%$ dari total wastage yang terjadi di PT XYZ atau sebanyak 1 cylinder cacat yang diakibatkan oleh masalah pinhole. 


\section{Kesimpulan dan Saran}

\subsection{Kesimpulan}

Pinhole merupakan permasalahan yang saling berkaitan sehingga untuk menangani masalah tersebut yaitu dengan cara:

a) Pembersihan AnodeNickel dilakukan dengan sikat Baja.

b) Seal yang dibuat disesuaikan dengan kebutuhan pemakaian (pembuatan sesuai jig).

c) CylinderBase / RM yang akan diproses terlebih dahulu dicek sesuai dengan WI yang telah dibuat.

d) Preventive maintenance untuk strainer, selenoid valve dan filter dilakukan oleh pihak produksi dan teknik.

e) WI pengamplasan, pencucian cylinder dan teknik handlingcylinder harus dijalankan.

f) Copper Nugget sisa di bawah Copper Anode dibersihkan setiap pergantian shift.

g) Current density yang digunakan $20 \mathrm{~A} / \mathrm{dm}^{2}$ dan dosing pump Additive $20 \mathrm{~s}$.

h) Air PAM yang digunakan untuk chiller diganti dengan Air RejectRO.

Dari hasil perbaikan yang sudah dilakukan dalam penanganan reject proses produksi di PT XYZ, bahwa perbaikan yang dilakukan sudah sangat efektif dalam penanganan masalah dominan yaitu pinhole. Hasil dari perbaikan didapatkan hasil akhir untuk wastage akibat Pinhole sebesar $4.00 \%$ dibandingkan dengan wastage awal sebelum dilakukan perbaikan yaitu sebesar $16.74 \%$. Jika dihitung selisih antara sebelum dilakukan perbaikan dan setelah dilakukan perbaikan, hasil improvement yang telah dilakukan berhasil menurunkan wastage sebesar $76.11 \%$ terhadap wastage total dan jika dibandingkan dengan total rejectpinhole didapatkan persentase sebesar $95.45 \%$.

\subsection{Saran}

Perbaikan yang sudah dilakukan sudah efektif.Perbaikan yang dilakukan dapat diterapkan secara permanen dan dievaluasi 6 bulan selanjutnya. Jika dilihat kembali pada proses perbaikan terdapat penanganan yang menimbulkan masalah lain yaitu mengenai adanya masalahbubble, hal tersebut sangat berkesinambungan terhadap proses treatment yang dilakukan pada saat penanganan pinhole, untuk itu setelah perbaikan ini dilakukan maka perbaikan selanjutnya yaitu mengenai penanganan bubble akibat treatmentpinhole.

\section{Daftar Pustaka}

1. Abrianto Akuan, Ir. MT. (2010). “Dasar-Dasar Proses Elektroplating”.Teknik Metalurgi - UNJANI.

2. Imai, Masaaki. (2012).Gemba Kaizen. McGraw Hill, New York.

3. Lilien, Otto M. (1972). “History of Industrial Gravure Printing up to 1920”. Lund Humphries London.

4. Rebros, M., Hrehorova, E., Bazuin, B.J., Joyce, M. K., Fleming, P. D., \& Perakorivicova, A. (2008). Rotogravure Printed UHF RFIsD Antennae directly on Packaging Materials. In Proceedings of the Technical Assosiation of the Grafhic Arts, TAGA. (pp. 292 - 304).

\section{LAMPIRAN}

\section{D Bushing Teflon Cyl}

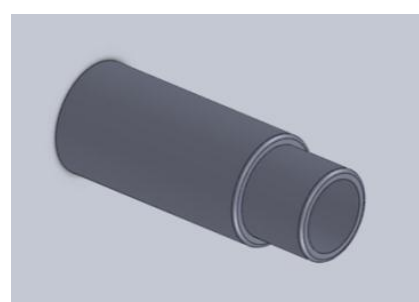

\section{Link Matric \& Needs}

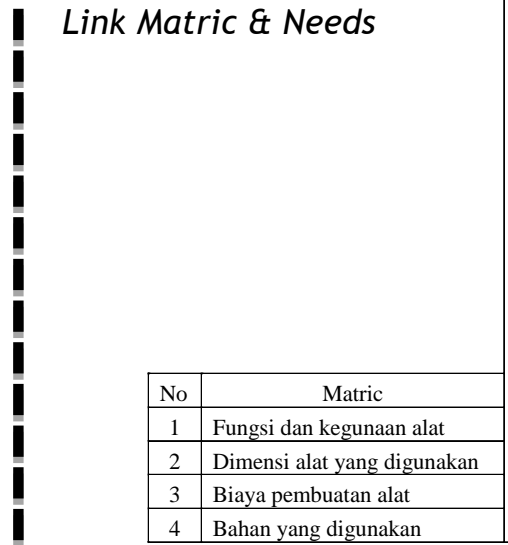


JIE, Vol. 3, No.2, September 2018: 119-128
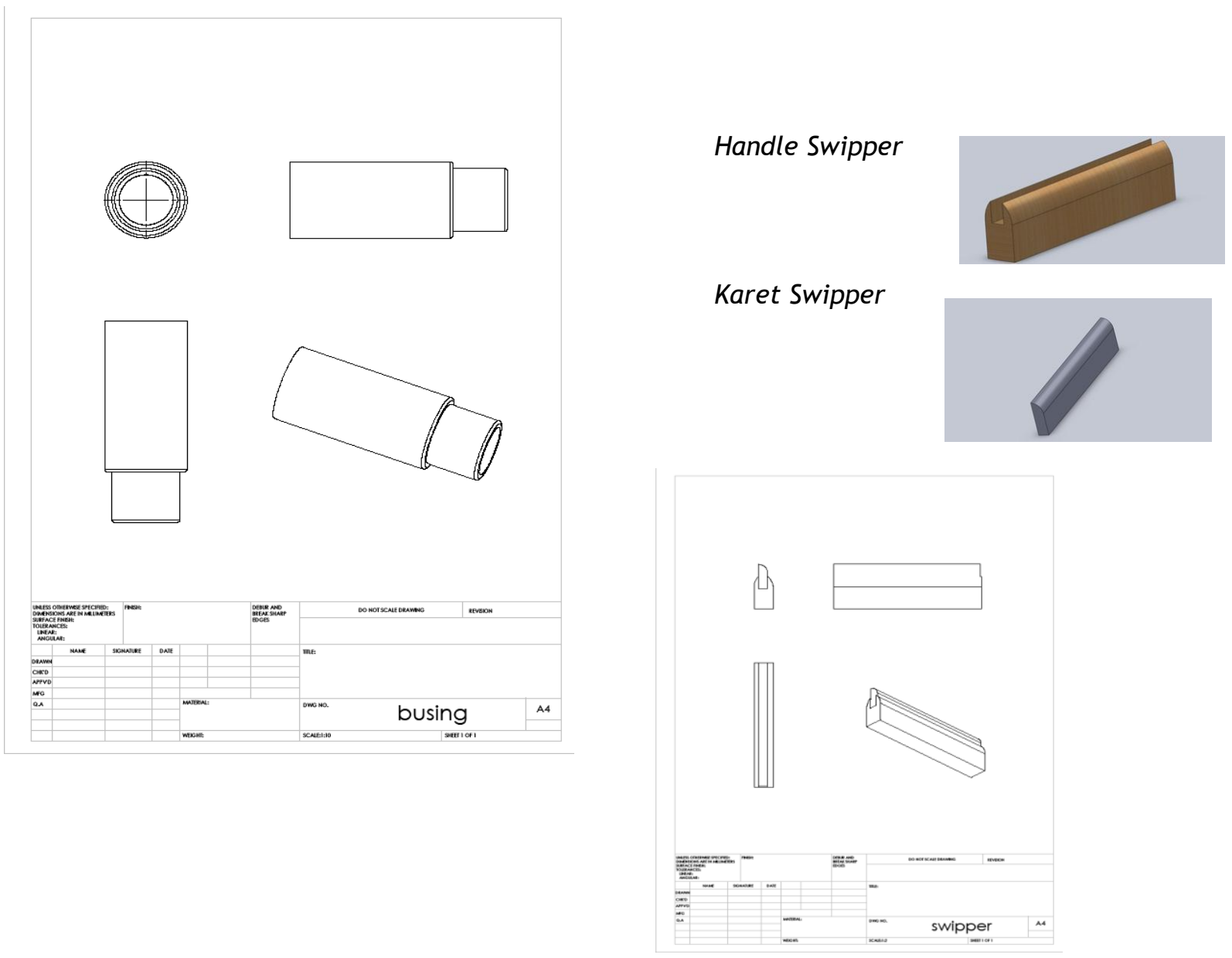